IZA DP No. 6522

On the Reversibility of Structural Reforms

Nauro F. Campos

Roman Horváth

April 2012 


\title{
On the Reversibility of Structural Reforms
}

\author{
Nauro F. Campos \\ Brunel University \\ and IZA \\ Roman Horváth \\ IES, Charles University
}

\section{Discussion Paper No. 6522 \\ April 2012}

\section{IZA}
P.O. Box 7240
53072 Bonn
Germany

Phone: +49-228-3894-0

Fax: +49-228-3894-180

E-mail: iza@iza.org

\begin{abstract}
Any opinions expressed here are those of the author(s) and not those of IZA. Research published in this series may include views on policy, but the institute itself takes no institutional policy positions.

The Institute for the Study of Labor (IZA) in Bonn is a local and virtual international research center and a place of communication between science, politics and business. IZA is an independent nonprofit organization supported by Deutsche Post Foundation. The center is associated with the University of Bonn and offers a stimulating research environment through its international network, workshops and conferences, data service, project support, research visits and doctoral program. IZA engages in (i) original and internationally competitive research in all fields of labor economics, (ii) development of policy concepts, and (iii) dissemination of research results and concepts to the interested public.
\end{abstract}

IZA Discussion Papers often represent preliminary work and are circulated to encourage discussion. Citation of such a paper should account for its provisional character. A revised version may be available directly from the author. 


\section{ABSTRACT}

\section{On the Reversibility of Structural Reforms*}

What are the factors that explain reversals in the implementation of structural reforms? Our main hypothesis is that reversals in different reforms are driven by different factors. This paper uses new reform indicators and presents novel evidence showing that (a) FDI inflows reduce the likelihood of privatization reversals, (b) worsened terms of trade increase the probability of external liberalization reversals and (c) labour strikes propel reversals in the liberalization of wages and prices.

JEL Classification: $\quad$ E23, D72, H26, O17

Keywords: reform reversals, price liberalization, trade liberalization, privatization, political economy

Corresponding author:

Nauro F. Campos

Brunel University

Department of Economics and Finance

Brunel University

London, UB8 3PH

United Kingdom

E-mail: nauro.campos@brunel.ac.uk

\footnotetext{
* We would like to thank László Bruszt, Fabrizio Coricelli, Gérard Duchêne, Saul Estrin, Jan Fidrmuc, Tomáš Havránek, Martin Gregor, likka Korhonen, Mathilde Maurel, František Turnovec, an anonymnous referee and seminar participants at EBRD (London), EPCS (Durham), BOFIT (Helsinki), University of Bologna, Oxford University, and Charles University (Prague) for valuable comments on earlier drafts. Evgeny Plaksen, Dana Popa and Ekaterina Shironosova provided superb research assistance. We thank the Economic and Social Research Council (ESRC), Research Project Grant RES-000-22-0550 for financial support. Horvath acknowledges the support from the Grant Agency of the Czech Republic No. P402/12/1993. All remaining errors are entirely our own.
} 


\section{Introduction}

One central task of the theoretical literature on the political economy of structural reforms is to investigate ways of designing reform packages that have a low probability of reversal (Alesina and Drazen, 1991, Dewatripont and Roland, 1995 Campos and Coricelli, forthcoming.) Despite the fact that reversibility occupies such a central place, there has been so far little systematic effort to identify empirically what are the main determinants of reform reversals. This paper contributes to this literature by examining empirically which factors drive the probability of reform reversals. Our main hypothesis is that different factors matter differently for different reforms. The main results provide strong confirmation: we find that FDI inflows reduce the likelihood of privatization reversals, worsened terms of trade and faster OECD growth increase the probability of external liberalization reversals, and labour strikes increase that of price liberalization reversals.

\section{Explaining Reform Reversals}

Measurement issues provide one main reason for why little is known about reform reversals. Most of the existing reform measures portray reforms as a smooth, uninterrupted process of continuous improvement where reversals occur only sparingly. This can be of course rationalized by policy-makers being clever and well-informed, political pressure on the international organizations constructing such measures (to not lower scores), or national authorities mistakenly understanding survey questions as referring to cumulative (instead of current) efforts. In this paper we use improved measures of reform efforts (prices and wages liberalization, external liberalization and privatization) in 25 Central and Eastern European countries. ${ }^{1}$ According to these measures, reforms are a more turbulent process characterized by experimenting, learning by doing, sudden advances and indeed sharp reversals. ${ }^{2}$

\footnotetext{
${ }^{1}$ A detailed presentation of these measures in available in Campos and Horvath (2012). The
} 
What are the factors that help to explain reform reversals? ${ }^{3}$ Unfavourable changes in economic conditions represent a possible reason for reform reversals (Dewatripont and Roland, 1995). An economic crisis, sudden increases in unemployment or slowdown in growth rates may affect the support for reform and cause reversals. Changes in political conditions are another set of potential reasons (Gehlbach and Malesky, 2010). For instance, turnovers in the major political party in government may make reversals more likely (for example, a left-wing succeeding a right-wing government).

Trying to reflect these ideas, we specify and estimate a random-effects logit model in which the dependent variable is coded 1 if there was a reversal in a particular reform in a given year for a given country, and zero otherwise:

$$
P\left(\text { reversal }_{i t c}=1\right)=\Phi\left(\beta_{0}+\beta_{1} \text { GDPgrowth }_{t c}+\beta_{2} \text { Unempl }_{t c}+\beta_{3} \text { Democracy }_{t c}+\beta_{4} V_{t c}\right)
$$

where reversal itc is a binary variable indicating whether reform $i$ in country $c$ at year $t$ has experienced a reversal (reversals are defined as a decrease in the value of a reform index in

motivation to construct alternative measures was that existing indexes (for instance, those constructed by the World Bank and EBRD) did not distinguish between reform inputs and outcomes, did not clarify the underlying variables nor the exact procedure used to aggregate these into reform indexes. In addition, there are various occasions when the aggregate indexes change but without corresponding changes in the underlying data constituting what has been called a "perverse vintage effect" (Campos and Horvath, 2012, p.229.)

${ }^{2}$ Merlevede (2003) calculates reform reversals using the EBRD indexes and reports that reversals are observed in only about $9 \%$ of the cases. Our three indexes, prices and wages liberalization, external liberalization and privatization, support more frequent reversals: $20.3 \%$ for external liberalization, $14.2 \%$ for prices and wages liberalization, and $18.1 \%$ for privatization. Merlevede (2003) reports that only half of the countries experienced reform reversals. According to the indexes we use in this paper, all countries experienced at least one reversal in one of the three reforms we consider.

${ }^{3}$ Notice that this exercise differs from the more standard one on reform dynamics, which explains both positive and negative variations from the mean. The bottom-half of the distribution of changes in the reform indicators (reversals) may well be driven by different factors than the mean itself. It may also be added that the question on the determinants of reform reversals has not been investigated as the focus has been mostly on the effects of reversals on growth (e.g., Merlevede, 2003). 
two consecutive years); GDPgrowth ${ }_{t c}$ is the rate of real per capita GDP growth, Unempl ${ }_{t c}$ is the unemployment rate, Democracy ${ }_{t c}$ is the Freedom House index of democracy; $V_{t c}$ is a vector of auxiliary control variables; and $\Phi$ is the cumulative logistic distribution function. ${ }^{4}$ We also consider an alternative dependent variable, a measure of the severity of reversals, namely the length of the reversal, that is how many times a reversal occurred consecutively (the dependent variable being 1 when reversal occurred, 2 when reversals occurred in two consecutive years, and so forth.)

\section{Econometric Results}

Table 1 presents our main results for three structural reforms (marginal effects are reported.) The first three columns show estimates for price and wage liberalization reversals. In this case, reversals seem driven primarily by political factors, more specifically by a direct form of protest (the number of general labour strikes). It is worth highlighting that factors that are often associated with the implementation of reforms (such as growth and democracy) seem to have little effect in explaining reform reversals (or indeed reversals duration). The importance of labour strikes raises the issue of the timing of reforms: because price liberalization was implemented before external liberalization and privatization, the most effective way to revert prices and wages liberalization seem to have been political influence.

The results with respect of the two other reforms are also interesting and intuitive. In the case of observed reversals of privatisation efforts, the main explanatory factor we find is FDI inflows as a share of GDP. This result is in line with a recent theoretical work by Mukherjeea and Suetrong (2009) which shows that FDI inflows affect government incentives for privatization. The main factors explaining external liberalisation are average growth rates

\footnotetext{
${ }^{4}$ Data sources are Penn World Tables, World Bank's World Development Indicators, UNCTAD Handbook of Statistics, and IMF Annual Report on Exchange Arrangements and Exchange
} 
of OECD economies (more favourable external conditions tempering the impetus to reform) and terms of trade (which have the opposite effect).

In Table 2 we re-estimate these specifications but instead of examining whether or not a reform reversal occurs, the focus is on their persistence (or duration). It reports randomeffects negative binomial estimates. Interestingly, the results for persistence are in line with those for reversals: we find that the occurrence of labour strikes seem to increase the duration of price liberalization reversals, OECD growth explains the persistence of external liberalization reversals and the lack of FDI inflows extends the duration of privatization reversals.

The results above were subjected to various robustness checks. For instance, we studied the inclusion of a number of potentially important variables, yet none of them proved to be systematically related to reform reversals. Specifically, there seem to be no systematic effects from inflation, financial crises, fiscal deficits, EU negotiations, war, timing of elections, ideological alternation in government, number of leadership changes, distance from Brussels, distance between capital cities, and whether or not the country was previously part of the Soviet Union (these results are available in the online Appendix). The results are similar with respect to the persistence of reform reversals, with few interesting exceptions. Two of them regarding the external liberalization index: inflation and being a former Soviet Union Republic increase the persistence (or severity) of external liberalization reversals. We also find that ideological alternation tends to increase the persistence of prices and wages liberalization reversals. Finally, we also find that using clustered standard errors by country or defining the starting of the transition as the year for which the country experienced the largest GDP fall do not qualitatively affect any of our main results. In short, we find no

Restrictions. See Campos and Horvath (2012) for further details. 
robust additional determinants of reform reversals (or of their persistence), while the principal results remained unchanged.

\section{Concluding remarks}

This paper offers a first empirical investigation into the determinants of reform reversals.

The econometric analysis highlights both economic and political factors: FDI inflows reduce the probability of privatization reversals, labour strikes increase that of prices and wages liberalization reversals, and OECD growth increase the likelihood of an external liberalization reversal. 


\section{References}

Alesina, A., Drazen, A., 2001. Why are stabilizations delayed? Amer. Econ. Rev. 81, 11701188 .

Campos, N.F., Coricelli, F., forthcoming, Financial liberalization and reversals: Political and economic determinants. Econ. Policy.

Campos, N. F., Horvath, R., 2012. Reform redux: Measurement, determinants and growth implications. Europ. J. Polit. Economy 28, 227-237.

Dewatripont, M., Roland, G., 1995. The design of reform packages under uncertainty. Amer. Econ. Rev. 85, 1207-23.

Gehlbach, S., Malesky, E.J., 2010. The contribution of veto players to economic reform. J. Polit. 72, 957-975.

Merlevede, B., 2003. Reform reversals and output growth in transition economies. Econ. Transition 11, 597-751.

Mukherjee, A., Suetrong, K., 2009. Privatization, strategic foreign direct investment and host-country welfare. Europ. Econ. Rev. 53, 775-785. 


\begin{tabular}{|c|c|c|c|c|c|c|c|c|c|}
\hline \multicolumn{10}{|c|}{$\begin{array}{c}\text { Table } 1 \\
\text { Determinants of reform reversals } \\
\text { Panel logit estimates } \\
\text { Sample of } 25 \text { transition economies, 1989-2005) }\end{array}$} \\
\hline & \multicolumn{3}{|c|}{$\begin{array}{c}\text { Reversal of } \\
\text { Prices and Wages Liberalization }\end{array}$} & \multicolumn{3}{|c|}{$\begin{array}{c}\text { Reversal of } \\
\text { External Liberalization }\end{array}$} & \multicolumn{3}{|c|}{$\begin{array}{r}\text { Reversal of } \\
\text { Privatization }\end{array}$} \\
\hline \multirow[t]{2}{*}{ Unemployment } & 0.045 & 0.050 & 0.038 & $0.062 * *$ & 0.007 & 0.038 & 0.024 & 0.028 & 0.028 \\
\hline & {$[0.030]$} & {$[0.040]$} & {$[0.041]$} & {$[0.026]$} & {$[0.027]$} & {$[0.048]$} & {$[0.027]$} & {$[0.031]$} & {$[0.032]$} \\
\hline \multirow[t]{2}{*}{ GDP growth } & 0.042 & $0.052 *$ & $0.058^{*}$ & $0.11^{* *}$ & 0.031 & 0.002 & -0.016 & -0.012 & -0.015 \\
\hline & {$[0.028]$} & [0.031] & {$[0.031]$} & {$[0.054]$} & {$[0.025]$} & {$[0.034]$} & {$[0.021]$} & {$[0.029]$} & {$[0.030]$} \\
\hline \multirow[t]{2}{*}{ Democracy } & -0.042 & -0.092 & -0.076 & -0.265 & 0.011 & 0.058 & 0.062 & -0.029 & -0.025 \\
\hline & {$[0.109]$} & {$[0.110]$} & {$[0.041]$} & {$[0.213]$} & {$[0.086]$} & {$[0.151]$} & {$[0.097]$} & {$[0.120]$} & {$[0.120]$} \\
\hline \multirow[t]{2}{*}{ Labor strikes } & & $0.825^{* *}$ & & & & & & & \\
\hline & & {$[0.335]$} & & & & & & & \\
\hline \multirow{2}{*}{ Labor strikes*Unempl. } & & & $0.112 * *$ & & & & & & \\
\hline & & & {$[0.040]$} & & & & & & \\
\hline \multirow[t]{2}{*}{ Growth OECD } & & & & & $1.28 * * *$ & $1.572 * * *$ & & & \\
\hline & & & & & {$[0.325]$} & {$[0.576]$} & & & \\
\hline \multirow{2}{*}{ Terms of trade } & & & & & & $-0.022 *$ & & & \\
\hline & & & & & & {$[0.012]$} & & & \\
\hline \multirow{2}{*}{ FDI inflows as \% GDP } & & & & & & & & $-0.229 * *$ & $-0.229 * *$ \\
\hline & & & & & & & & {$[0.117]$} & {$[0.116]$} \\
\hline \multirow[t]{2}{*}{ Fiscal balance } & & & & & & & & & 0.015 \\
\hline & & & & & & & & & {$[0.038]$} \\
\hline Observations & 260 & 232 & 233 & 250 & 243 & 147 & 228 & 175 & 175 \\
\hline No. of countries & 25 & 24 & 24 & 23 & 25 & 25 & 25 & 25 & 25 \\
\hline McFadden R-squared & 0.13 & 0.24 & 0.25 & 0.41 & 0.25 & 0.69 & 0.10 & 0.33 & 0.36 \\
\hline
\end{tabular}

Notes: The three liberalization indexes are measured in a zero to 1 scale with higher values indicating more reform. Reversal is defined as a decrease in the value of the index in consecutive years, with the absolute value used in the estimation. Random effects panel estimates reported based on Hausman test. Robust standard errors in brackets. *,**,*** indicate statistically significant at 10,5 and $1 \%$ level, respectively. Marginal effects reported. 


\begin{tabular}{l} 
Table 2 \\
Determinants of the persistence of reform reversals \\
Negative binomial estimates \\
(Sample of 25 transition economies, 1989-2005) \\
\begin{tabular}{|l|c|c|c|c|c|c|c|c|c|}
\hline \multicolumn{1}{|l|}{ Duration of reversal of } & Duration of reversal of \\
Privatization
\end{tabular} \\
\hline \\
\hline
\end{tabular}

Notes: The three liberalization indexes are measured in a zero to 1 scale with higher values indicating more reform. Duration of reversals is defined as a consecutive decrease in the value of the index, with the dependent variable taking the value of 1 if reversals occur in two consecutive years, two if it occurs in an additional consecutive year, and so forth. Random effects negative binomial panel estimates reported based on Hausman test. Robust standard errors in brackets. *,**,*** statistically significant at significant at 10,5 and $1 \%$ level, respectively. Marginal effects reported. 
APPENDIX 
Table A1

The determinants of prices and wages liberalization reversals Panel logit estimates

\begin{tabular}{|c|c|c|c|c|c|c|c|c|c|}
\hline \multirow[t]{2}{*}{ GDP growth } & 0.058 & 0.006 & 0.045 & 0.052 & 0.057 & 0.05 & 0.05 & 0.052 & 0.052 \\
\hline & -0.036 & -0.049 & -0.033 & $(0.031)+$ & $(0.032)+$ & -0.032 & -0.031 & $(0.031)+$ & $(0.031)+$ \\
\hline Unemployment & 0.065 & 0.055 & 0.053 & 0.05 & 0.052 & 0.051 & 0.04 & 0.049 & 0.05 \\
\hline \multirow[t]{2}{*}{ Freedom H. Index } & -0.12 & 0.032 & -0.081 & -0.091 & -0.071 & -0.048 & -0.004 & -0.092 & -0.092 \\
\hline & -0.117 & -0.147 & -0.111 & -0.121 & -0.113 & -0.147 & -0.14 & -0.11 & -0.11 \\
\hline Strikes & 0.826 & 2.042 & 0.822 & 0.825 & 0.823 & 0.823 & 0.735 & 0.825 & 0.822 \\
\hline \multirow[t]{2}{*}{ Log of inflation } & 0.1 & & & & & & & & \\
\hline & -0.138 & & & & & & & & \\
\hline \multicolumn{2}{|c|}{ Financial crisis indicator } & 51.428 & & & & & & & \\
\hline & & -38.022 & & & & & & & \\
\hline Fiscal deficit & & & 0.024 & & & & & & \\
\hline \multirow[t]{2}{*}{ Electoral calendar } & & & & & 0.015 & & & & \\
\hline & & & & & -0.143 & & & & \\
\hline \multicolumn{2}{|c|}{ Leadership changes (cum.) } & & & & & 0.124 & & & \\
\hline & & & & & & -0.28 & & & \\
\hline \multicolumn{2}{|c|}{ Political alternation (cum.) } & & & & & & 0.275 & & \\
\hline & & & & & & & -0.264 & & \\
\hline \multicolumn{2}{|c|}{ Distance between capital cities } & & & & & & & 0.0001 & \\
\hline & & & & & & & & $(0.001)$ & \\
\hline \multirow[t]{2}{*}{ FSU vs. non-FSU } & & & & & & & & & 0.0001 \\
\hline & & & & & & & & & -0.002 \\
\hline
\end{tabular}

Robust standard errors in parentheses. + significant at $10 \%$;* significant at $5 \%$; significant at $1 \%$. Marginal effects reported. 
Table A2

The determinants of external liberalization reversals Panel logit estimates

\begin{tabular}{|c|c|c|c|c|c|c|c|c|c|}
\hline \multirow[t]{2}{*}{ GDP growth } & 0.052 & 0.042 & 0.032 & 0.03 & 0.031 & 0.033 & 0.029 & 0.033 & 0.027 \\
\hline & $(0.029)+$ & -0.038 & -0.025 & -0.025 & -0.025 & -0.025 & -0.025 & -0.025 & -0.025 \\
\hline Unemployment & 0.02 & 0.001 & 0.005 & 0.007 & 0.004 & 0 & 0.015 & 0.004 & 0.009 \\
\hline \multirow[t]{2}{*}{ Freedom H. Index } & 0.014 & -0.026 & 0.023 & 0 & 0.005 & -0.073 & -0.067 & 0.012 & 0.011 \\
\hline & -0.09 & -0.113 & -0.087 & -0.095 & -0.088 & -0.125 & -0.112 & -0.086 & -0.086 \\
\hline OECD growth & 1.367 & 0.927 & 1.314 & 1.296 & 1.29 & 1.347 & 1.329 & 1.268 & 1.321 \\
\hline \multirow[t]{2}{*}{ Log of inflation } & 0.155 & & & & & & & & \\
\hline & -0.115 & & & & & & & & \\
\hline \multicolumn{2}{|c|}{ Financial crisis indicator } & -8.547 & & & & & & & \\
\hline & & -8.027 & & & & & & & \\
\hline Fiscal deficit & & & -0.024 & & & & & & \\
\hline \multirow[t]{2}{*}{ Electoral calendar } & & & & & 0.025 & & & & \\
\hline & & & & & -0.104 & & & & \\
\hline \multicolumn{2}{|c|}{ Leadership changes (cum.) } & & & & & -0.233 & & & \\
\hline & & & & & & -0.254 & & & \\
\hline \multicolumn{2}{|c|}{ Political alternation (cum.) } & & & & & & -0.276 & & \\
\hline & & & & & & & -0.258 & & \\
\hline \multicolumn{2}{|c|}{ Distance between capital cities } & & & & & & & 0.0001 & \\
\hline & & & & & & & & $(0.001)$ & \\
\hline \multirow[t]{2}{*}{ FSU vs. non-FSU } & & & & & & & & & -0.006 \\
\hline & & & & & & & & & $(0.003)^{* *}$ \\
\hline
\end{tabular}

Robust standard errors in parentheses. + significant at 10\%; ** significant at 5\%; $*$ significant at $1 \%$. Marginal effects reported. 
Table A3

The determinants of privatization reversals

Panel logit estimates

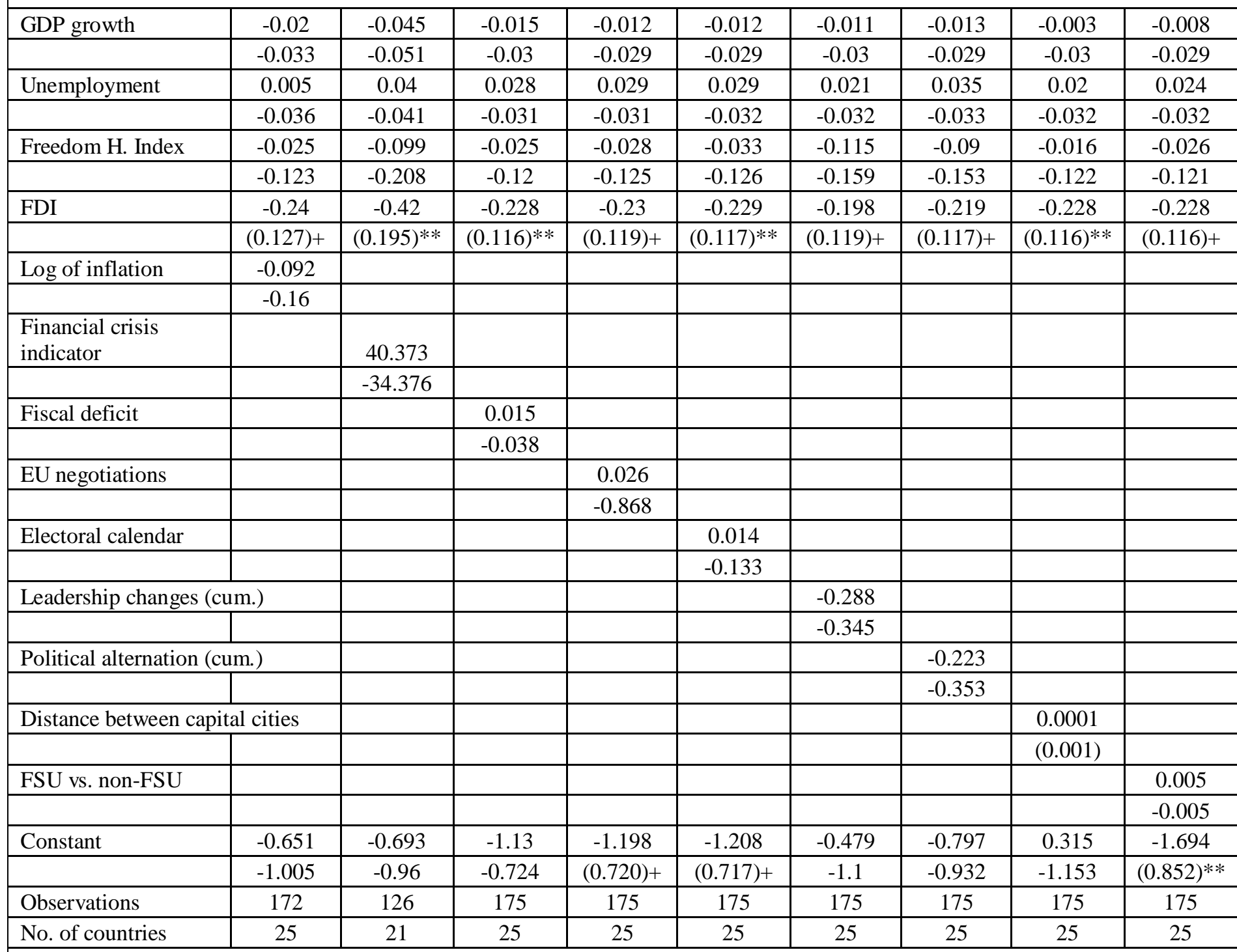

Robust standard errors in parentheses. + significant at 10\%; ** significant at 5\%; * significant at $1 \%$. Marginal effects reported. 
Table A4

The determinants of the persistence of prices and wages liberalization reversals Negative binomial estimates

\begin{tabular}{|c|c|c|c|c|c|c|c|c|c|}
\hline \multirow[t]{2}{*}{ GDP growth } & 0.058 & -0.006 & 0.039 & 0.043 & 0.046 & 0.039 & 0.039 & 0.042 & 0.042 \\
\hline & $(0.032)+$ & -0.043 & -0.03 & -0.029 & -0.029 & -0.029 & -0.028 & -0.029 & -0.029 \\
\hline Unemployment & 0.056 & 0.043 & 0.047 & 0.046 & 0.047 & 0.044 & 0.027 & 0.045 & 0.048 \\
\hline \multirow[t]{2}{*}{ Freedom H. Index } & -0.172 & 0.004 & -0.14 & -0.15 & -0.131 & -0.074 & -0.024 & -0.147 & -0.146 \\
\hline & $(0.103)+$ & -0.133 & -0.108 & -0.112 & -0.109 & -0.136 & -0.122 & -0.107 & -0.107 \\
\hline Strikes & 0.896 & 1.39 & 0.824 & 0.804 & 0.813 & 0.81 & 0.768 & 0.811 & 0.788 \\
\hline \multirow[t]{2}{*}{ Log of inflation } & 0.156 & & & & & & & & \\
\hline & -0.109 & & & & & & & & \\
\hline \multicolumn{2}{|c|}{ Financial crisis indicator } & 16.879 & & & & & & & \\
\hline & & -12.974 & & & & & & & \\
\hline Fiscal deficit & & & 0.012 & & & & & & \\
\hline \multirow[t]{2}{*}{ Electoral calendar } & & & & & 0.027 & & & & \\
\hline & & & & & -0.128 & & & & \\
\hline \multicolumn{2}{|c|}{ Leadership changes (cum.) } & & & & & 0.203 & & & \\
\hline & & & & & & -0.237 & & & \\
\hline \multicolumn{2}{|c|}{ Political alternation (cum.) } & & & & & & 0.383 & & \\
\hline & & & & & & & $(0.213)+$ & & \\
\hline \multicolumn{2}{|c|}{ Distance between capital cities } & & & & & & & 0.0001 & \\
\hline & & & & & & & & $(0.001)$ & \\
\hline \multirow[t]{2}{*}{ FSU vs. non-FSU } & & & & & & & & & -0.001 \\
\hline & & & & & & & & & -0.002 \\
\hline
\end{tabular}

Robust standard errors in parentheses. + significant at 10\%; ** significant at 5\%; $*$ significant at $1 \%$. Marginal effects reported. 
Table A5

The determinants of the persistence of external liberalization reversals

Negative binomial estimates

\begin{tabular}{|c|c|c|c|c|c|c|c|c|c|}
\hline GDP growth & 0.072 & 0.069 & 0.049 & 0.052 & 0.051 & 0.053 & 0.051 & 0.054 & 0.05 \\
\hline & $(0.024)^{*}$ & $(0.033) * *$ & $(0.022)^{* *}$ & $(0.022) * *$ & $(0.022)^{* *}$ & $(0.022)^{* *}$ & $(0.022) * *$ & $(0.027)^{* *}$ & $(0.022)^{* * *}$ \\
\hline \multirow[t]{2}{*}{ Unemployment } & 0.012 & -0.003 & 0 & 0.001 & -0.004 & -0.003 & 0.006 & 0.087 & 0.002 \\
\hline & -0.021 & -0.025 & -0.021 & -0.021 & -0.021 & -0.022 & -0.021 & $(0.051)+$ & -0.021 \\
\hline \multirow[t]{2}{*}{ Freedom H. Index } & 0.051 & 0.032 & 0.063 & 0.055 & 0.05 & 0.015 & 0 & -0.094 & 0.057 \\
\hline & -0.066 & -0.092 & -0.067 & -0.075 & -0.067 & -0.096 & -0.085 & -0.204 & -0.067 \\
\hline \multirow[t]{2}{*}{ OECD growth } & 0.888 & 0.534 & 0.817 & 0.816 & 0.819 & 0.847 & 0.848 & 0.688 & 0.831 \\
\hline & $(0.250)^{*}$ & $(0.283)+$ & $(0.249)^{*}$ & $(0.253)^{*}$ & $(0.251)^{*}$ & $(0.255)^{*}$ & $(0.252)^{*}$ & $(0.268)^{* *}$ & $(0.251)^{*}$ \\
\hline \multirow[t]{2}{*}{ Log of inflation } & 0.155 & & & & & & & & \\
\hline & $(0.084)+$ & & & & & & & & \\
\hline \multirow[t]{2}{*}{ Financial crisis indicator } & & -7.438 & & & & & & & \\
\hline & & -6.433 & & & & & & & \\
\hline \multirow[t]{2}{*}{ Fiscal deficit } & & & -0.002 & & & & & & \\
\hline & & & -0.03 & & & & & & \\
\hline \multirow[t]{2}{*}{ EU negotiations } & & & & 0.002 & & & & & \\
\hline & & & & -0.422 & & & & & \\
\hline \multirow[t]{2}{*}{ Electoral calendar } & & & & & 0.006 & & & & \\
\hline & & & & & -0.081 & & & & \\
\hline \multicolumn{2}{|l|}{ Leadership changes (cum.) } & & & & & -0.113 & & & \\
\hline & & & & & & -0.2 & & & \\
\hline \multicolumn{2}{|l|}{ Political alternation (cum.) } & & & & & & -0.202 & & \\
\hline & & & & & & & -0.201 & & \\
\hline \multicolumn{2}{|c|}{ Distance between capital cities } & & & & & & & 0.0001 & \\
\hline & & & & & & & & $(0.001)$ & \\
\hline \multirow[t]{2}{*}{ FSU vs. non-FSU } & & & & & & & & & -0.004 \\
\hline & & & & & & & & & $(0.002)+$ \\
\hline \multirow[t]{2}{*}{ Constant } & 4.858 & 12.532 & 9.736 & 10.497 & 5.239 & 9.444 & 2.861 & 4.843 & 10.616 \\
\hline & -48.102 & -667.583 & -510.242 & -474.889 & -66.19 & -561.459 & -20.573 & -195.138 & -442.249 \\
\hline Observations & 237 & 151 & 236 & 243 & 241 & 243 & 243 & 231 & 243 \\
\hline No. of countries & 25 & 21 & 25 & 25 & 25 & 25 & 25 & 23 & 25 \\
\hline
\end{tabular}




\section{Table A6}

The determinants of the persistence of privatization reversals Negative binomial estimates

\begin{tabular}{|c|c|c|c|c|c|c|c|c|c|}
\hline GDP growth & -0.011 & -0.018 & -0.006 & -0.003 & -0.003 & -0.002 & -0.004 & 0.002 & 0.001 \\
\hline & $(-0.028)$ & $(-0.042)$ & $(-0.025)$ & $(-0.025)$ & $(-0.025)$ & $(-0.025)$ & $(-0.025)$ & $(-0.026)$ & $(-0.025)$ \\
\hline \multirow[t]{2}{*}{ Unemployment } & 0.005 & 0.033 & 0.022 & 0.023 & 0.022 & 0.017 & 0.03 & 0.017 & 0.019 \\
\hline & $(-0.032)$ & $(-0.035)$ & $(-0.026)$ & $(-0.026)$ & $(-0.027)$ & $(-0.026)$ & $(-0.027)$ & $(-0.026)$ & $(-0.027)$ \\
\hline \multirow[t]{2}{*}{ Freedom H. Index } & -0.012 & -0.051 & -0.017 & -0.02 & -0.015 & -0.09 & -0.089 & -0.011 & -0.017 \\
\hline & $(-0.108)$ & $(-0.175)$ & $(-0.104)$ & $(-0.107)$ & $(-0.109)$ & $(-0.133)$ & $(-0.13)$ & $(-0.104)$ & $(-0.105)$ \\
\hline \multirow[t]{2}{*}{ FDI } & -0.256 & -0.406 & -0.238 & -0.238 & -0.239 & -0.209 & -0.226 & -0.232 & -0.238 \\
\hline & $(0.118)^{* *}$ & $(0.171)^{* *}$ & $(0.109)^{* *}$ & $(0.111)^{* *}$ & $(0.109)^{* *}$ & $(0.111)+$ & $(0.108) * *$ & $(0.112)^{* *}$ & $(0.109) * *$ \\
\hline \multirow[t]{2}{*}{ Log of inflation } & -0.089 & & & & & & & & \\
\hline & $(-0.136)$ & & & & & & & & \\
\hline \multicolumn{2}{|c|}{ Financial crisis indicator } & 32.118 & & & & & & & \\
\hline & & $(-28.317)$ & & & & & & & \\
\hline \multirow{2}{*}{ Fiscal deficit } & & & 0.013 & & & & & & \\
\hline & & & $(-0.033)$ & & & & & & \\
\hline \multirow[t]{2}{*}{ EU negotiations } & & & & -0.044 & & & & & \\
\hline & & & & $(-0.784)$ & & & & & \\
\hline \multirow[t]{2}{*}{ Electoral calendar } & & & & & -0.014 & & & & \\
\hline & & & & & $(-0.112)$ & & & & \\
\hline \multicolumn{2}{|c|}{ Leadership changes (cum.) } & & & & & -0.249 & & & \\
\hline & & & & & & $(-0.293)$ & & & \\
\hline \multicolumn{2}{|c|}{ Political alternation (cum.) } & & & & & & -0.265 & & \\
\hline & & & & & & & $(-0.311)$ & & \\
\hline \multicolumn{2}{|c|}{ Distance between capital cities } & & & & & & & 0.0001 & \\
\hline & & & & & & & & $(0.001)$ & \\
\hline \multirow[t]{2}{*}{ FSU vs. non-FSU } & & & & & & & & & 0.004 \\
\hline & & & & & & & & & $(-0.004)$ \\
\hline \multirow[t]{2}{*}{ Constant } & 11.788 & 14.803 & 11.931 & 11.784 & 11.755 & 12.693 & 12.821 & 3.52 & 13.55 \\
\hline & -737.865 & $(1,153.991)$ & -769.76 & -657.948 & -762.545 & -714.062 & $(1,024.420)$ & -6.657 & -496.707 \\
\hline Observations & 172 & 126 & 175 & 175 & 175 & 175 & 175 & 175 & 175 \\
\hline No. of countries & 25 & 21 & 25 & 25 & 25 & 25 & 25 & 25 & 25 \\
\hline
\end{tabular}

